\title{
SKRINNING RHIZOBAKTERI MANGROVE Rhizosphora Sp. PENGHASIL AMILASE
}

\author{
Siti Nurfajriah $^{1^{*}}$, Maulin Inggraini ${ }^{2}$, Noor Andryan Ilsan ${ }^{3}$ \\ 1. Program Studi DIII Analis Kesehatan STIKes Mitra Keluarga, Bekasi-Indonesia \\ 2. Program Studi DIII Analis Kesehatan STIKes Mitra Keluarga, Bekasi-Indonesia \\ 3. Program Studi DIII Analis Kesehatan STIKes Mitra Keluarga, Bekasi-Indonesia
}

*Korespondensi: Siti Nurfajriah | STIKes Mitra Keluarga | fajriah.sn@ gmail.com

\begin{abstract}
Abstrak
Pendahuluan: Ekosistem mangrove merupakan ekosistem yang kaya akan nutrisi karena dipengaruhi oleh pasang surut air laut, asupan air tawar dari daratan, akumulasi mineral, dan aktivitas mikroorganisme. Kondisi tersebut menghasilkan ekosistem yang unik dan memiliki keanekaragaman mikroorganisme. Rhizobakteri adalah bakteri yang hidup pada daerah rhizosfer dan membentuk koloni pada sistem perakaran tumbuhan. Rhizobakteri diketahui memiliki bermacam enzim, salah satunya antara lain enzim amilase. Enzim amilase banyak digunakan di industri makanan, tekstil, dam kertas.

Metode: Tujuan penelitian ini adalah mengisolasi dan menskrining amilase yang dihasilkan rizhobakteri dari tanaman mangrove dan bakteri serasah pada mangrove Rhizophora Sp. Isolasi bakteri dilakukan dengan seri pengenceran yang ditumbuhkan dalam medium zobell. Skrinning aktivitas amilase dilakukan dengan menumbuhkan bakteri dalam medium zobell agar yang mengandung pati.

Hasil: Isolat rhizobakteri yang berhasil diisolasi dari tumbuhan mangrove muda, mangrove tua, dan serasah berjumlah 42 isolat. Hasil skrining menunjukkan 30 isolat mampu menghasilkan $\alpha$-amilase.

Kesimpulan: Berdasarkan penelitian dapat disimpulkan bahwa isolat Rhizobakteri mangrove yang berhasil diisolasi dari akar tanaman mangrove Pulau Bira Kepulauan Seribu sebanyak 42 isolat dan 30 isolat menghasilkan enzim $\alpha$ amilase. Isolat yang paling banyak menghasilkan enzim tersebut berasal dari rhizobakteri tanaman mangrove muda dan zona bening yang yang terbesar yaitu $7 \mathrm{~mm}$.
\end{abstract}

Kata Kunci : $\alpha$-amilase, Mangrove, Rhizobakteri

Diterima 22 November 2018; Accepted 30 Desember 2018

\section{PENDAHULUAN}

Ekosistem mangrove dikenal sebagai salah satu ekosistem yang dinamik karena dipengaruhi oleh pasang surut air laut, asupan air tawar dari daratan, akumulasi mineral, dan aktivitas mikroorganisme (Soedrajat, 2003). Kondisi tersebut menyebabkan mangrove mengandung banyak nutrisi dan memiliki keragamaan mikroorganisme yang dapat beradaptasi dengan kondisi ekstrim (Bhat \& Shewade, 2013). Mikroorgnisme yang hidup di daerah mangrove antara lain bakteri, jamur dan actinomycetes. Karakteristik bakteri yang hidup di mangrove umumnya bersifat halofilik. Bakteri halofilik menghasilkan enzim - enzim yang tidak mudah rusak pada kondisi ekstrem sehingga banyak digunakan dalam bidang industri. Habitat bakteri dapat ditemukan di tanah, sedimen mangrove, endofit yang bersimbiosis dengan tanaman, dan rhizosfer tanaman mangrove. Penelitian sebelumnya menunjukkan bahwa hidrolase halofilik seperti amilase, lipase, dan protease dihasilkan oleh bakteri halofilik sedimen mangrove (Debarti, Paradita, Arpita, \& Malini, 2016), padahal aktivitas enzim di rhizosfer umumnya lebih tinggi daripada di tanah (Gianfreda , 2015). Penelitian mengenai rhizobakteri halofilik yang berasal dari rhizosfer tanaman mangrove di Indonesia masih jarang dilakukan, sehingga perlu dilakukan eksplorasi untuk menemukan rhizobakteri yang mampu memproduksi enzim dan antibakteri.

Rhizobakteri adalah bakteri yang hidup pada daerah rhizosfer dan membentuk koloni pada sistem perakaran tumbuhan. Rhizosfer memiliki ketersediaan nutrisi melimpah yang berasal dari kegiatan fotosintesis, fiksasi nitrogen, dan metanogenesis. Oleh karena itu, rhizosfer merupakan lingkungan yang kaya akan keanekaragaman bakteri. Rhizobakteri menghasilkan berbagai macam enzim hidrolitik dan dapat meningkatkan pertumbuhan tanaman dengan menghasilkan fitohormon. Hasil penelitian menunjukkan bahwa rhizobakteri tanaman Aegle marmelos memiliki aktivitas enzim amilase, phosphatase, katalase, oksidase, urease, dan kaseinase (Damle \& Kulkarni, 2012). Pada umumnya, enzim hidrolitik bersifat ekstraseluler karena menghidrolisis molekul besar menjadi molekul kecil yang dilepaskan oleh bakteri ke 
lingkungan dan digunakan dalam metabolisme bakteri. Selain itu, enzim ekstraseluller lebih mudah diperoleh dan dimurnikan dibandingkan enzim intraseluller.

Amilase merupakan enzim yang paling banyak digunakan dalam bidang industri antara lain makanan, kertas, dan tekstil. Amilase (EC 3.2.1.1) merupakan enzim kelas hidrolase yang berfungsi menghidrolisis pati menjadi glukosa, maltose, dan maltotriosa (Mohsen \& Fahime, 2012). Mengingat luasnya penggunaan enzim- enzim tersebut dalam dunia industri dan masih sedikitnya penelitian mengenai rhizobakteri dari tanaman mangrove maka pada penelitian ini akan dilakukan skrinning rhizobakteri mangrove penghasil amilase.

\section{METODE}

Pengambilan sampel dilakukan di Pulau Bira, Kepulaan Seribu. Pengambilan sampel dilakukan dengan mengambil tanah di sekitar perakaran $(1-5 \mathrm{~mm})$, yang menempel pada bagian rhizosfer tanaman mangrove, dan serasah di hutan mangrove. Sampel rhizospher dan serasah tanaman mangrove diambil secara aseptis, kemudian dimasukan ke dalam plastik sampel. Bahan yang digunakan bakto agar (Merck), media zobell (Merck), air laut, pati (Merck), lugol iodin (Merck). Sampel rhizosfer dan serasah tanaman mangrove dimasukkan ke dalam erlenmeyer yang telah berisi $100 \mathrm{~mL}$ air laut steril, kemudian dihomogenkan dengan menggunakan shaker selama 15 menit dan diperoleh pengenceran $10^{-1}$. Larutan dari pengenceran $10^{-1}$ diambil $1 \mathrm{~mL}$ menggunakan mikropipet kemudian ditambahkan $9 \mathrm{~mL}$ air laut steril dan diperoleh pengenceran $10^{-2}$. Perlakuan yang sama dilakukan hingga diperoleh pengenceran $10^{-3}$ dan $10^{-4}$. Pada pengenceran $10^{-3}$ dan $10^{-4}$ diambil $1 \mathrm{~mL}$ suspensi bakteri menggunakan mikropipet, kemudian dispread ke masing-masing cawan petri berisi medium Zobell agar steril (Setyati \& Subagiyo, 2012). Cawan petri tersebut diinkubasi selama 2 × 24 jam pada suhu $36{ }^{\circ} \mathrm{C}$.

Pemurnian isolat bakteri menggunakan metode goresan. Koloni bakteri yang menampakan morfologi dan warna yang berbeda dari masing- masing cawan petri hasil pengenceran $10^{-3}$ dan $10^{-4}$ diambil dan digoreskan kembali ke medium Zobell agar steril. Cawan petri diinkubasi selama 1 x 24 jam pada suhu 36 ${ }^{\circ} \mathrm{C}$. Selanjutnya, bakteri dalam cawan petri diamati pertumbuhannya. Bakteri yang sudah terpisah atau murni dilakukan tahap seleksi. Koloni tunggal bakteri diinokulasikan ke dalam medium Zobell agar yang telah berisi pati $1 \%$. Isolat bakteri diinkubasi selama 1 x 24 jam pada suhu $36{ }^{\circ} \mathrm{C}$. Penentuan adanya aktivitas enzim menggunakan larutan lugol iodin 1\%. Larutan lugol iodin $1 \%$ dituang di atas kultur, adanya zona bening menunjukkan adanya aktivitas amilase. Karakteristik morfologi bakteri yang diperiksa meliputi bentuk dan warna. Data hasil pengamatan dianalisis secara deskriptif dengan memperhatikan morfologi koloni isolat serta pengukuran zona aktivitas yang terbentuk pada masing-masing medium seleksi.

\section{HASIL}

Hasil penelitian menunjukkan terdapat 42 isolat rhizobakteri yang berhasil diisolasi dari mangrove genus rhizosphora Sp. dan serasah mangrove adalah 42 isolat (Tabel 1).

Tabel 1. Jumlah Isolat Rhizobakteri Mangrove di Pulau Bira Kepulauan Seribu

\begin{tabular}{clcc}
\hline No & \multicolumn{1}{c}{ Sumber } & Kode & $\begin{array}{c}\text { Jumlah } \\
\text { Isolat }\end{array}$ \\
\hline 1. & Tanaman & A & 16 \\
mangrove muda & & \\
2. & $\begin{array}{l}\text { Tanaman } \\
\text { mangrove tua }\end{array}$ & $\mathrm{B}$ & 9 \\
3. & Serasah & $\mathrm{C}$ & 8 \\
4. & Serasah & $\mathrm{D}$ & 9 \\
& \multicolumn{1}{c}{ Total } & & 42 \\
\hline
\end{tabular}

Hasil isolasi tehadap 42 isolat rhizobakteri mangrove menunjukkan bahwa 30 isolat mampu menghasilkan $\alpha$-amilase (Tabel 2). 
Tabel 2. Aktivitas Enzim Ekstraseluler Rhizobakteri Mangrove Pulau Bira Kepulauan Seribu

\begin{tabular}{|c|c|c|}
\hline No & Kode Isolat & $\begin{array}{l}\text { Aktivitas Amilase }(\mathrm{D}= \\
\mathbf{m m})\end{array}$ \\
\hline 1 & A 1.3 & 7 \\
\hline 2 & A 1.4 & 1 \\
\hline 3 & A 1.5 & 4 \\
\hline 4 & A 1.8 & 6 \\
\hline 5 & A 1.11 & 6 \\
\hline 6 & A 2.6 & 2 \\
\hline 7 & A 2.11 & 6 \\
\hline 8 & A 3.1 & 3 \\
\hline 9 & A 3.2 & 1 \\
\hline 10 & A 3.5 & 4 \\
\hline 11 & B 1.1 & 3 \\
\hline 12 & В 1.3 & 2 \\
\hline 13 & B 1.4 & 2 \\
\hline 14 & В 1.5 & 5 \\
\hline 15 & В 1.7 & 2 \\
\hline 16 & B 3.1 & 2 \\
\hline 17 & B 3.2 & 1 \\
\hline 18 & B 3.3 & 1 \\
\hline 19 & C 1.8 & 5 \\
\hline 20 & C 2.9 & 4 \\
\hline 21 & C 2.10 & 3 \\
\hline 22 & D 1.2 & 4 \\
\hline 23 & D 1.3 & 6 \\
\hline 24 & D 2.3 & 3 \\
\hline 25 & D 2.6 & 1 \\
\hline 26 & D 2.9 & 6 \\
\hline 27 & D 3.1 & 2 \\
\hline 28 & D 3.3 & 2 \\
\hline 29 & D 3.5 & 1 \\
\hline 30 & D 3.6 & 0.5 \\
\hline
\end{tabular}

Isolat rhizobakteri yang memiliki aktivitas amilase terbanyak berasal dari akar tanaman mangrove muda (A) yaitu 10 isolat. Diameter zona aktivitas $\alpha$-amilase berkisar $0,5-7 \mathrm{~mm}$. Isolat yang memiliki aktivitas $\alpha$-amilase tertinggi adalah A 1.3, A 1.8, A 1.11, A 2.11, D 1.3, dan D 2.9 (Gambar 1).

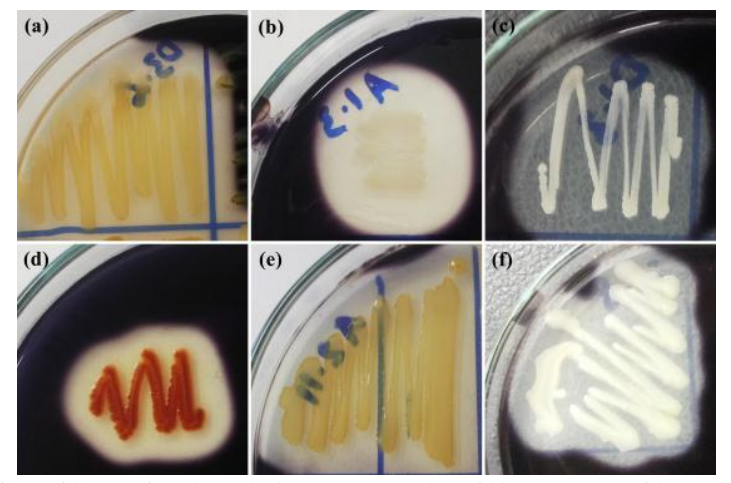

Gambar 1. Zona bening yang dihasilkan isolat dalam menghasilkan $\alpha$-amilase (a) Isolat D3.6, (b) A1.3, (c), D1.3, (d) D2.9, (e) A2.11, (f) A1.8.

Morfologi rhizobakteri dan serasah tanaman mangrove pada penelitian ini paling banyak adalah bakteri gram negatif dan berbentuk monococcus (Tabel 3). 
Tabel 3. Morfologi Isolat Rhizobakteri Mangrove di Pulau Bira Kepulauan Seribu

\begin{tabular}{|c|c|c|c|}
\hline No & $\begin{array}{l}\text { Kode } \\
\text { Isolat }\end{array}$ & Gram & Bentuk \\
\hline 1 & A 1.3 & $\mathrm{ND}$ & ND \\
\hline 2 & A 1.4 & ND & ND \\
\hline 3 & A 1.5 & Negatif & Monococcus \\
\hline 4 & A 1.8 & ND & ND \\
\hline 5 & A 1.11 & ND & ND \\
\hline 6 & A 2.6 & Negatif & Monococcus \\
\hline 7 & A 2.11 & ND & ND \\
\hline 8 & A 3.1 & ND & ND \\
\hline 9 & A 3.2 & ND & ND \\
\hline 10 & A 3.5 & ND & ND \\
\hline 11 & В 1.1 & ND & ND \\
\hline 12 & В 1.3 & Positif & Monococcus \\
\hline 13 & В 1.4 & Negatif & Monococcus \\
\hline 14 & В 1.5 & Negatif & Monococcus \\
\hline 15 & В 1.7 & Negatif & Monococcus \\
\hline 16 & В 3.1 & Positif & Monococcus \\
\hline 17 & B 3.2 & ND & ND \\
\hline 18 & В 3.3 & Negatif & Monococcus \\
\hline 19 & C 1.8 & Negatif & Monococcus \\
\hline 20 & C 2.9 & negatif & Monobasil \\
\hline 21 & C 2.10 & negatif & Monobasil \\
\hline 22 & D 1.2 & negatif & Monobasil \\
\hline 23 & D 1.3 & negatif & Monococcus \\
\hline 24 & D 2.3 & Negatif & Monococcus \\
\hline 25 & D 2.6 & Negatif & Monococcus \\
\hline 26 & D 2.9 & Negatif & Monobasil \\
\hline 27 & D 3.1 & positif & Sterptobasil \\
\hline 28 & D 3.3 & Negatif & Monococcus \\
\hline 29 & D 3.5 & Negatif & Monococcus \\
\hline 30 & D 3.6 & ND & ND \\
\hline
\end{tabular}

\section{PEMBAHASAN}

Tanaman mangrove dapat beradaptasi terhadap berbagai tipe sedimen, perubahan temperatur, nutrisi, kadar garam dan oksigen. Eksosistem mangrove mempunyai keanekaragaman mikroorganisme yang memiliki kemampuan menghasilkan enzim ekstraseluler yang diperlukan untuk perombakan bahan organik. Beberapa penelitian menunjukkan bahwa bakteri heterotropik di ekosistem mangrove menghasilkan enzim ektraseluler diantaranya amilase, protease, esterase, dan lipase. Hasil penelitian menunjukkan bahwa aktivitas enzim protease paling tinggi dari bakteri yang berasal dari sedimen kawasan mangrove (Setyati \& Subagiyo, 2012).

Pada penelitian ini dilakukan skrining $\alpha$-amilase terhadap rhizobakteri dan serasah tanaman mangrove. Uji adanya aktivitas $\alpha$-amilase berdasarkan kemampuan enzim dalam menghidrolisis pati. Isolat yang dianggap positif menghasilkan $\alpha$-amilase membentuk zona bening setelah ditetesi larutan lugol iodin pada medium zobel agar yang mengandung pati (Padhiar \& Kommu, 2016). Hal ini dikarenakan pati dalam medium tersebut sudah terhidrolisis menjadi disakarida atau monosakarida. Wilayah zona biru tua terjadi akibat reaksi lugol iodin dengan pati yang tidak terhidrolisis.

$\alpha$-amilase dikeluarkan oleh bakteri yang menghidrolisis pati (senyawa polisakarida) yang ada di lingkungan luar sel menjadi senayawa yang lebih sederhana lagi (disakarida atau monosakarida). $\alpha$-amilase merupakan enzim ekstraseluler yang dihasilkan dari dalam sel dan dikeluarkan ke media fermentasi. Di luar sel, enzim ini mendegradasi polisakarida menjadi senyawa sederhana yang mudah larut sehingga mudah diserap oleh dinding sel dan dijadikan sebagai sumber energi. Pati oleh rhizobakteri merupakan sebagai sumber karbon untuk sumber energi bagi kelangsungan hidupnya.

Enzim $\alpha$-amilase digunakan dalam berbagai industri makanan, detergen, dan obat-obatan. Industri pati 
memanfaatkan $\alpha$-amilase dalam proses pencairan pati menjadi sirup fruktosa dan glukosa, serta industri roti. Konversi pati secara enzimatik meliputi proses gelatinisasi, pencairan, dan sakarifikasi. Penambahan $\alpha$-amilase ke dalam adonan roti dapat meningkatkan volume, dan tekstur, adanya rasa manis, dan meningkatkan kualitas (Mohsen \& Fahime, 2012), $\alpha$-amilase berperan penting dalam industri detergen. $\alpha$ amilase berfungsi menghilangkan noda dimana pati yang berasal dari makanan menjadi senyawa lebih sederhana yang mudah larut dan menjaga keputihan pakaian (Rajendra, Anshumali, Manoj, \& Praven, 2016). Industri farmasi juga memanfaatkan $\alpha$-amilase sebagai matriks biodegradable polisakarida atau bahan penyalut obat. Hal ini dikarenakan bahan matriks tersebut dapat di degradasi secara alami menyerupai pati sehingga terjadi secara alamiah di dalam tubuh. Pati pragelatinisasi dan pati cross-linked telah digunakan sebagai hidrogel. Penambahan $\alpha$-amilase ke cross-linked amylose (CLA) tablet dapat memodulasi kinetika menghancuran obat (Mohsen dan Fahime, 2012).

\section{KESIMPULAN}

Berdasarkan penelitian dapat disimpulkan bahwa isolat Rhizobakteri mangrove yang berhasil diisolasi dari akar tanaman mangrove Pulau Bira Kepulauan Seribu sebanyak 42 isolat dan 30 isolat menghasilkan enzim $\alpha$-amilase. Isolat yang paling banyak menghasilkan enzim tersebut berasal dari rhizobakteri tanaman mangrove muda dan zona bening yang yang terbesar yaitu $7 \mathrm{~mm}$.

\section{REFERENSI}

Bhat, M. R., \& Shewade, L. (2013). Isolation and Characterization of Microorganisms from Mangrove Soil of CBD Belapur Creek, Navi Mumbai, MS India. International Journal of Enviroment Sciences, 3(6), 2304-2312.

Damle, N. R., \& Kulkarni, S. W. (2012). Enzymatic Potential of Bacteria Isolated From Rhizosphere of Aegle Marmelos (Bael Tree). World Journal of Enviromental Biosciences, 1(2), 86-89.

Debarti, H., Paradita , D., Arpita , M., \& Malini, B. (2016, July). Isolation and Charcaterization of Halophilic Bacteria From Sundarban Soil. Int.J.Life.Sci.Scienti.Res, 2(4), 442-450.

Gianfreda , L. (2015). Enzymes of Importance of Rhizosphere Processes. Journal of Soil Science and Plant Nutrition, 15(2), 283-306.

Mohsen, M. D., \& Fahime, A. J. (2012). Application of Alpha-Amylase in Biotechnology. Journal of Biology and Today's World, 1(1), 15-20.

Padhiar, A. R., \& Kommu, S. (2016). Isolation, Charcterization, and Optimazation of Bacteria Producing Amylase. International Journal of Advanced Research in Biological Sciences, 3(7), 1-7.

Rajendra, S., Anshumali, M., Manoj, K., \& Praven, K. M. (2016). Amylase: A Note on Current Application. International Research Journal of Biological Sciences, 5(11), 27-32.

Setyati, W. A., \& Subagiyo. (2012, September). Isolasi dan Seleksi Bakteri Penghasil Enzim Ekstraseluler (Proteolitik, amilolitik, lipopitik, dan selulolitik) yang Berasal dari Sedimen Kawasan Mangrove. Ilmu Kelautan, 17(3), 164-168.

Soedrajat, R. (2003). Fungsi Model Hidrodinamika dalam Pengelolaan Ekosistem Mangrove (Studi Kasus Pencemaran Minyak di Estuari Sungai Donan Cilacap. Berkala Penelitian Hayati, 8(2), 81-84. 